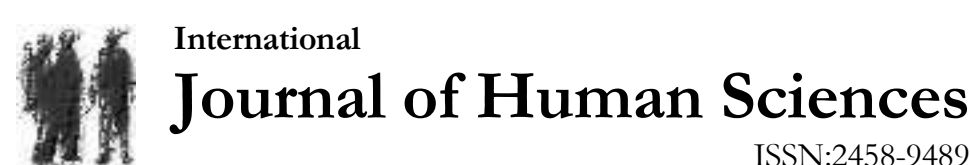

Volume: 18 Issue: 1 Year: 2021

\section{The survival of the "weakest" among the fittest: A critical reading of Miss Julie (1889) in relation to social Darwinism}

\author{
Selçuk Şentürk ${ }^{1}$ \\ Zeynep Şentürk ${ }^{2}$
}

\begin{abstract}
The play Miss Julie is about the portrayal of the new image of feminist woman in the Victorian period. The playwright August Strindberg is mainly considered to be a misogynist as evidenced in his preface to Miss Julie, in which he defines miss Julie as man-hating and half woman with a "degenerate brain". This representation of Miss Julie by a male author is likely to promote the idea that Strindberg presents the new 'feminist' woman as inferior and weak with a downfall in the end. However, the paper will dwell into the play by employing reader-response criticism to interpret the play and discover its multiple meanings rather than following the mainstream readings that rely on characteristics of the Victorian period. By employing a critical reading method, the paper will attempt to problematize social Darwinism in relation to gender roles as represented in the play, and by doing so it will challenge if not transform the social constructions of "weak women" that ideologically pertains today.
\end{abstract}

Keywords: Gender roles; social Darwinism; Victorian period; reader response criticism.

\section{Introduction}

Works of literature represent if not mirror the societies we live in even at some points they anticipate the challenges we as human are likely go through. Miss Julie written in 1888 by the Swedish playwright August Strindberg is not an exception to this fact. The play is about gender relations and domination of women by patriarchal system that remain significant and relevant even today. The Victorian society was shaped and sustained by gender roles that classified women and men as two distinct sexes with different roles on them. While men were considered to be better at the public realm as the provider of the family, women were confined to the private realm with domestic responsibilities on them. The Victorian conventions and norms promoted the very idea that gender roles are biologically determined rather than socially constructed. This idea was ideologically placed on "scientific grounds" by social Darwinism, reinforcing the classification of humans as inferior and superior in a hierarchal order. This would potentially make the so-called superior a norm according to which "the inferior" is defined. When it comes to gender roles, this hierarchal order would

\footnotetext{
${ }^{1}$ Assistant Professor, Kafkas University, Faculty of Science and Letters, Department of English Language and Literature, s.senturk36@gmail.com (iD) Orcid ID: 0000-0002-6084-4032

2 Lecturer, Kafkas University, School of Foreign Languages, senturk.zeynep.okumus@gmail.com

(iD) Orcid ID: 0000-0003-1105-9502
} 
Şentürk, S., \& Şentürk, Z. (2021). The survival of the "weakest" among the fittest: A critical reading of Miss Julie (1889) in relation to social Darwinism. Journal of Human Sciences, 18(1), 104-109. doi:10.14687/jhs.v18i1.6140

"naturally" place women into a secondary position and concern after men, impeding the new image of feminist woman. Although the play seems to be reinforcing the ideological assumptions about gender roles, considering the author and conditions of the period, it implicitly bears potential readings that would celebrate, if not promote, the new image of feminist woman. Roland Barthes (1977, p. 148) suggests that "a text's unity lies not its origin but in its destination", highlighting the key role of readers in discovering novel albeit contradictory meanings embedded in the text. This paper, having the play Miss Julie at the centre will exemplify how readers can reshape the meaning by their own experiences and perceptions contrary to the perceived mainstream message carried by conditions that created the work.

The world in the $19^{\text {th }}$ century witnessed several social, economic, and scientific developments. These developments have paved the way for social change on a global scale. However, women remained members of the oppressed class as the social developments mostly shaped by scientific advancements considered their status secondary to men. The perceived inferior status of women has been sustained by patriarchal system, a "social construction" which gives the priority to men and enables him to occupy every field of life (Creamer, 2016, p. 8). Hence, patriarchal codes reinforced the ideology that men are the norm by, and around which women have been defined for centuries. To comply with their predefined roles in relation to family and society, women of the Victorian age tried to possess good moral behaviour and train themselves to be a good wife and a mother in the family. Therefore, the ideology of the society in the Victorian age imposed a subordinate position to women and confined them to their household. Furthermore, Radek states that if women failed their position as a wife and a mother there would be even legal and moral consequences (2008, as cited in Creamer, 2016, p. 9). That would mean a confirmation of the idea that women in their families and societies were dependent on their roles determined by patriarchal codes.

In the patriarchal atmosphere of the Victorian era, women were considered secondary to men and were made to put aside their own desires and interests at the expense of others (Davari, 2015). The means of education they received were only those that were suitable for an ideal Victorian woman such as embroidery and the ways to raise children. They were denied the same privileges in terms of education that was mostly offered to men. That would naturally mean having limited opportunities to improve themselves mentally and as Woolf (1929) puts it "women have had less intellectual freedom than the sons of Athenian slaves" (p. 116). This being the case, they were perceived both physically and mentally weak in comparison to men and treated accordingly.

Towards the end of the $19^{\text {th }}$ century, Charles Darwin, an English biologist made an outbreak about the world of science with his evolution and natural selection theory. Later, his works were termed as Darwinism and as Hawkins (1997) states, it is a "biological theory about how new species are formed and existing ones can become extinct" (p. 24). Darwin traced the history of men back to apes and emphasized how the fittest of living species would overcome extinction and keep up with their environment. Moreover, Charles Darwin (1871) in his book The Descent of Man and Selection in relation to Sex, made a distinction between men and women, claiming the former to be more "courageous" and "energetic" (p. 413). And furthermore, he asserted that men are more equipped in terms of reasoning, intellectual and physical activities. This illustration by Darwin, paved the way for a new ideology to be called 'social Darwinism'. This term was mainly supported by Herbert Spencer, an English philosopher who penned the term 'the survival of the fittest' that Darwin later employed in his studies.

In his book The Study of Sociology Spencer (1873/2002) observed several distinctions between men and women through their psychological and biological traits. His classification promotes the inferior and superior positions that women and men are successively positioned "... qualitative distinctions between the minds of men and women are those which have grown out of their mutual relation as stronger and weaker" (p. 375). According to Spencer, as stated in Darwin's Natural Selection theory, human society is also engaged in a struggle "for status and power" (Rebellato, 2010, p. 11). This is presumed to be a natural process in which individuals compete with each other to gain dominance over others and become the strongest and fittest. The promotion of this school of 
Șentürk, S., \& Șentürk, Z. (2021). The survival of the "weakest" among the fittest: A critical reading of Miss Julie (1889) in relation to social Darwinism. Journal of Human Sciences, 18(1), 104-109. doi:10.14687/jhs.v18i1.6140

thought placed 'women' in a lower status as they were seen mentally and physically weaker than men. Lerner (1986) asserted that with the development of Darwinian theories in the 19th century, women were considered to be scientifically inferior and their role was confined to production and then reproduction of human species as a result of their biological and feminine nature. Furthermore, the term natural selection and biological progress that Darwin identified suited Spencer's view of social progress among human society (Rogers, 1972). This led him to verify his ideas and separate the unfit societies from the innately superior population. Spencer also regarded women inferior and indicated that they lack intellectual capacity because they use up their energy for household chores and child raising activities (Hawkins, 1997). As a consequence of gender ideology supported by scientific grounds in this era, women were mainly voiceless, submissive and oppressed.

Despite the confinement of women to domestic sphere, there were also strong-willed women who were eager to make their voices heard. Among these were Mary Astell, Mary Wollstonecraft and Virginia Woolf. According to Anderson (2006), the Enlightenment movement during the late 17th and 18th century-initiated liberalism which prepared an intellectual atmosphere for feminism to emerge and later gain a momentum in the 19th century. With the help of this empowerment movement, women started realising their own needs and started upheavals against the traditional social and cultural norms. Mary Astell who has been regarded as the first female English feminist reprimanded women for showcasing themselves as mere ornaments and showing no initiative for self-improvement. She further stated that instead of giving importance to "material body" they should focus on their "immaterial essence" (Bryson, 1998, p. 42). At that time, the Victorian society was not in favour of feminist ideals as it was taken as an attempt to deny the true and very nature of women. However, there were interestingly enough male playwrights such as Henrik Ibsen and August Strindberg, who implicitly advocated this complex albeit new image of woman by voicing woman concerns in their works.

Writers were also addressing the economic position of women as one of the key factors to way out from their submission to the male authority. Woolf's acclaimed work $A$ Room of One's Own reveals the very necessity of economic freedom for women to create a space for themselves. This space albeit physical indeed can be considered a locus where women can free their minds to challenge gender stereotypes of the Victorian society. The play Miss Julie is about the portrayal of this new image of feminist woman in the Victorian period. The author of the play August Strindberg is mainly considered to be a misogynist and in his preface to Miss Julie, Strindberg (1888b) defines her as "manhating half woman [who has a] degenerate brain" (p. 141). Consequently, this representation of a woman might be interpreted with the idea that Strindberg presents the new 'feminist' woman as inferior and weak with a downfall in the end. However, this paper will dwell into the play by employing reader-response criticism in a way that would celebrate the experiences of the reader to interpret the play. Charles Bressler (1994) states that the text itself is open to interpretation while the reader is no more the "passive receiver of knowledge" but someone who is active in the process of creating a text (p. 48). Henceforth, the readers' understanding of the work can open diverse meanings that could even at points might contradict the authors' intended message.

The play Miss Julie takes place in a kitchen during the midsummer evening with only three on stage characters. The protagonist miss Julie is the count's daughter and after having several turns dancing with her father's valet Jean, they begin to form an intimate relationship. This relationship starts very flirtatious at first but moves into a shameful one at the end. And Kristin, the maid in the kitchen also Jean's fiancé is only preoccupied with her duties and religious beliefs. The fact that the play runs in a kitchen hints women's confinement to domestic spheres; however, Miss Julie's refusal of her father's invitation for the celebration and preferring to spend time with the servants could be read as her self-determination.

August Strindberg was well acquainted with the German philosopher Friedrich Nietzsche and under his influence, he regarded the world as two separate divisions of "the naturally weak and naturally strong" (Rebellato, 2010, p. 13). Here the quote hints the ways in which that Strindberg comments on the contradictory albeit intersecting relation between the weak and the strong. The 
Șentürk, S., \& Șentürk, Z. (2021). The survival of the "weakest" among the fittest: A critical reading of Miss Julie (1889) in relation to social Darwinism. Journal of Human Sciences, 18(1), 104-109. doi:10.14687/jhs.v1811.6140

world is in a constant clash between these the weak and the strong in which the latter defines and controls the earlier. This clash evokes Darwinian evolutionary concept of "the survival of the fittest", which in the case of the Victorian society can be applied on gender division between men and women. This division was one of the fundamental facets of the Victorian society where the ideals of strong and weak are biologically and ideologically determined. In the play, the protagonist miss Julie stands for the weak trying to survive among the fittest. It can be observed that miss Julie opts for dominance over men she acquaints with such as her fiancé and Jean as pointed out by Jain (2015) starts the "battle between the sexes" (p. 164). Miss Julie's treatment of her fiancé as a dog and ordering Jean to kiss her foot are examples of power and dominance over the opposite gender. However, as the sexes battle there appears a reversal as the fiancé breaks off the engagement and Jean takes control over miss Julie after the intimate relationship between the two. Strindberg's characterization of miss Julie is complex and unconventional that problematize social and cultural norms in the Victorian period. Strindberg (1888a) highlights the fact through his portrayal of Jean as he repeats "off her head...She's off her head" (p. 51). The phrase 'off her head' emphasizes the new degenerate woman to be illogical and mad.

Throughout the play, we learn about miss Julie's mother and how she burned down their house. According to Davari and Sadeghi (2017), burning the house down symbolizes the mothers' rebellion against the social hierarchy. Moreover, bringing her daughter up lie a boy and reversing the household duties among men and women propose that no difference exists between the sexes. Like miss Julie, the mother also yearns for her freedom from patriarchal codes and looks for empowering female qualities. The difference between them is the issue of money. The mother possessed more power than Julie as the latter says in the play " $[\mathrm{m}] \mathrm{y}$ mother had a small fortune. She didn't want my father to manage it" (p. 60). The capital that the mother owned gave her power and freedom to burn down the house and rebel against her husband's wishes. She also hid the money from her husband as he could maintain it for himself after their marriage. On the other hand, miss Julie fights against patriarchy and social norms but she cannot complete her mission due to lack of economic freedom. In the play, when Julie states she has no money, Jean immediately discards their plan of escape, showing escape becomes meaningful as long as economic freedom is attained.

In Miss Julie, Jean the valet acts out everything but his line of work. He starts out as a dancer to miss Julie, fiancé to Kristin later becomes a liar, opportunist, and a hypocrite. In his preface, Strindberg (1888b) portrays him as the strongest due to his gender and declares Jean to be superior to miss Julie as he has masculine characteristics. However, the work of Davari and Sadeghi (2017) indicated that Strindberg reveals antipathy for both in relation to the emerging image of 'new woman' as represented by miss Julie. He further expresses discontent for the working class by illustrating Jean as a fraud. Hence, it can be inferred that Strindberg's portrayal of the 'fittest' and 'strongest' male character actually represents the hypocrisy and desire for an upward mobility towards higher classes.

In the play, miss Julie appears to be superior in terms of class but the dominant patriarchal society considers Jean to be superior and advantageous on the basis of his biology. In terms of emancipation, miss Julie desires to have equal rights as men and disputes the social hierarchy. She wants Jean to call her Julie several times and says that they are equals especially after their intimate encounter. The possibility of an ongoing intimacy between the two on equal terms fails when Jean refuses miss Julie. Therefore, the unexpected breakdown of this relationship results in a mental breakdown, causing Julie to have contradictory emotions. This is can be observed in her contradictory behaviours that perpetuate: “can't run away, can't stay, I cannot live, I cannot die. Help me. Bark me an order and I'll obey like a dog" (p. 67). The confusion she is going through is explicit as she demands Jean to order her which she would never have done before.

At the end of the play, the mental breakdown that miss Julie goes through becomes clearer and, it is translated in her relationship with others. She pleads help from both Kristin and Jean. She sees Kristin as a port of refuge because she is a woman and miss Julie discards the social rank between them "Kristin, help me. Save me from this man[...]You're a woman, [...]you're my friend" (p. 65). However, instead of helping her mistress, she regards her paranoiac and tell her " $[\mathrm{t}]$ he last shall be 
Șentürk, S., \& Șentürk, Z. (2021). The survival of the "weakest" among the fittest: A critical reading of Miss Julie (1889) in relation to social Darwinism. Journal of Human Sciences, 18(1), 104-109. doi:10.14687/jhs.v18i1.6140

the first [...] it is easier for a camel to pass through the eye of a needle than for a rich man to enter the Kingdom of God" (p. 66). Kristin declares that there is no good place where miss Julie can go. Germaine Greer (1986) states that despite his misogyny, Strindberg presents the patriarchal norms and the struggle between genders as more honest and bare than the works of Ibsen or Shaw (as cited in Rebellato, 2010, p. 14). In the play, Strindberg portrays Kristin as an obedient and religious person but it can be observed at the same time that the author suggests her 'the devout Christian' to be distrustful and selfish.

\section{Conclusion}

The play ends as miss Julie goes out of the kitchen with a shaving razor that Jean handed to her so that she can commit suicide. Hence Strindberg emphasizes the difference between men and women as the former is "better equipped for evolution and [...] survival" while the latter just want to bring destruction upon themselves (Singh, 2014, p. 18). The act of committing suicide with a shaving razor, which could be interpreted as symbol for patriarchy and masculinity hints the ways in which miss Julie's attempt to liberate from traditional norms and patriarchal codes. Although ending one's life might signal a defeat, it could indeed be read metaphorically as a way to challenge social conformity and a cry for the protagonist's self-determination over her being. Moi (2002) highlights that behind the angel of the house, there hides a monster that acts out freely and who has a "story to tell" (p. 57). Miss Julie becomes the monster that patriarchy hates and lives on forever to tell her story for the coming generations. Although literary works such as Miss Julie created at that time seemingly portrayed struggling images of women, they indeed brought concerns and demands of women to the forefront. These representations created the ways in which the conditions of women at that time could critically be observed. Strindberg portrays Julie to be degenerate man-hating woman who destroys herself in the end. However, rather than following the Victorian ideals before her and surviving a life as expected from "the weakest", miss Julie prefers defying predefined roles and codes set for her. In this way, her challenge against the patriarchy survives as "the strongest", echoing in decades to come. During the 19th century, with scientifically grounded ideologies such as social Darwinism, patriarchy gained power, explicitly defining women inferior and submissive to men. And several scientific works highlighted the difference between women and men over their biological differences. However, works of literature created the ways in which the intervention of science into to private and public realms could be questioned.

\section{References}

Andersen, M. L. (2006). Thinking about women: Sociological perspectives on Sex and Gender (7th ed.). Pearson and $\mathrm{AB}$.

Barthes, R. (1977). Image, music, text. Fontana Press.

Bryson, C. (1998). Mary Astell: Defender of the "Disembodied Mind". Hypatia, 13(4), 40-62. Retrieved March 15, 2021, from http://www.jstor.org/stable/3810502

Creamer, S. (2016). Slamming the door on patriarchy. The treatment of transgressive women in Henrik Ibsen's works. Retrieved from https://esource.dbs.ie/handle/10788/2992

Darwin, C. (1871). The Descent of man and selection in relation to sex. John Murray.

Davari, H. (2015). A Marxist reading of Miss Julie. International Letters of Social and Humanistic Sciences, 64, 109-118.

Davari, H. \& Sadeghi, M. (2017). A dialectical reading of Strindberg's Miss Julie. Journal of Humanistic \& Social Studies, 8(2), 57-71.

Hawkins, M. (1997). Social Darwinism in European and American thought 1860-1945. Cambridge University Press.

Jain, S. (2015). Miss Julie: A psychoanalytic study. Journal of Transdisciplinary Studies, 8(2), 161-176.

Lerner, G. (1986). The creation of patriarchy. Oxford University Press.

Moi, T. (2002). Sexual/ textual politics (2nd ed.). Routledge Taylor and Francis Group. 

in relation to social Darwinism. Journal of Human Sciences, 18(1), 104-109. doi:10.14687/jhs.v18i1.6140

Radek, R. (2008). From Medusa to Cleopatra. Retrieved November 15, 2020, from Women in Literature, www2.ivcc.edu/gen2002/greek_and_roman_women.htm.

Rebellato, D. (2010). Naturalism and Symbolism: Early Modernist practice. In M.B. Gale \& J.F. Deeney (Eds.), The Routledge Drama Anthology and Sourcebook (3-163). Routledge.

Rogers, J. A. (1972). Darwinism and social Darwinism. Journal of the History of Ideas, 33(2), 265-280.

Shideler, R. (1997). Darwin, weak men, strong women and Ibsen's pillars of society. Comparative Literature Studies, 34(3), 242-259.

Singh, A. D. (2014). Sexual, textual and traumatic subjectivity: August Strindberg representation of class and sexual conflict in Miss Julie. Journal of Research in Humanities and Social Science, 2(10), $18-20$.

Spencer, H. (1873). The study of sociology. Henry S. King \& Co.

Strindberg A. (1888a). Miss Julie. In M. B. Gale \& J. F. Deeney (Eds.), The Routledge Drama Anthology and Sourcebook (51-67). Routledge.

Strindberg A. (1888b). Preface to Miss Julie. In M. B. Gale \& J. F. Deeney (Eds.), The Routledge Drama Anthology and Sourcebook (138-146). Routledge.

Woolf, V. (1929). A Room of One's Own. Renard Press. 